\title{
"Green bonds of supranational financial institutions: On the road to sustainable development"
}

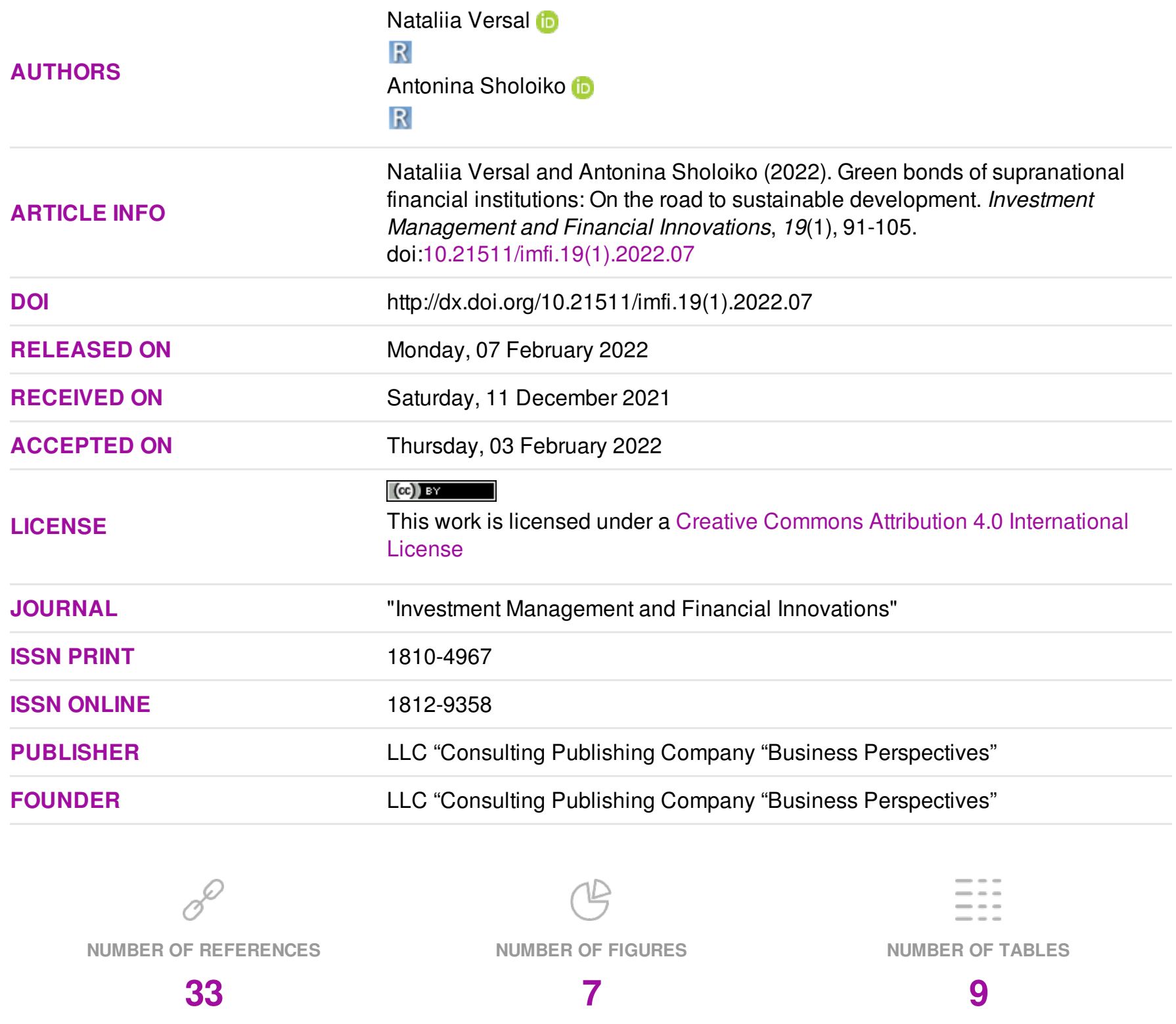

(c) The author(s) 2022. This publication is an open access article. 


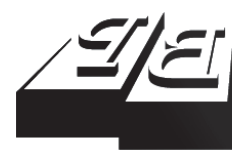

BUSINESS PERSPECTIVES

(O)

LLC "CPC "Business Perspectives"

Hryhorii Skovoroda lane, 10,

Sumy, 40022, Ukraine

www.businessperspectives.org
Received on: $11^{\text {th }}$ of December, 2021 Accepted on: $3^{\text {rd }}$ of February, 2022 Published on: $7^{\text {th }}$ of February, 2022

(c) Nataliia Versal, Antonina Sholoiko, 2022

Nataliia Versal, Doctor of Economics, Associate Professor, Taras Shevchenko National University of Kyiv, Ukraine.

Antonina Sholoiko, Doctor of Economics, Associate Professor, Taras Shevchenko National University of Kyiv, Ukraine. (Corresponding author)

\title{
GREEN BONDS
}

OF SUPRANATIONAL FINANCIAL INSTITUTIONS: ON THE ROAD TO SUSTAINABLE DEVELOPMENT

\begin{abstract}
The move to sustainable development and building a carbon-low economy needs funding. In this regard, a new direction in finance - green (sustainable) finance - has emerged. One of the green finance instruments is green bonds, first issued by supranational financial institutions. This paper aims to identify the features of green bond issues and implemented green projects by the World Bank (the WB) and the European Bank for Reconstruction and Development (the EBRD). Data were obtained from databases and reports of the WB, the EBRD, and the Climate Bonds Initiative. Data analysis was provided using statistical methods, particularly descriptive and comparative statistics. A positive trend in the issue of green bonds in the volumes and timing of the WB and the EBRD was revealed, despite the shift in emphasis caused by COVID-19. Renewable energy, energy efficiency, and clean transportation remain the primary directions of the $\mathrm{WB}$, and the EBRD green projects amounted to more than $60 \%$ of total projects funding. The geography of green projects financed through the $\mathrm{WB}$ and the EBRD green bonds indicates that green projects are receiving significant funding from countries facing environmental challenges and demonstrating intent to green transition (the WB - China and India, the EBRD - Turkey, Poland, and Egypt). Supranational financial institutions were the first to come to the forefront of sustainable development funding and are now spearheading the creation of new financial instruments aimed at financing both green and social projects, leading to the emergence of sustainability bonds.
\end{abstract}

\section{Keywords}

climate change, Sustainable Development Goals, environmental sustainability, green finance, the World Bank, the EBRD

\section{JEL Classification F34, G15, O19, Q01}

\section{INTRODUCTION}

As is commonly known, the growth of social welfare and economic development have their price. This price skyrockets due to environmental issues, which lead nowadays to a discernible shift from the usual understanding of economic development, which was formed in the 19th-20th centuries, to sustainable development, based on the achievement of 17 Sustainable Development Goals (SDG). If these goals were defined rather broadly and vaguely at first, now they are taking the form of SMART goals. For example, more and more countries claim that they will achieve carbon neutrality by $2040-2060$ (Amundi, IFC, 2020). However, SDG achievement also comes at a price. Furthermore, comparing prices in monetary terms, they can be significantly higher for sustainable development than for classical economic development, and therefore there is a danger of giving up and returning to old technologies. However, over time, under the influence of technology development, a significant decrease in prices is possible, as happened in the electricity sector. So, if solar energy in 2010 costed 378 US dollars per MWh, then in 2019 it was 68 US dollars, while nuclear energy has increased in price, respectively, from 96 Us dollars to 155 US dollars 
(Roser, 2021). At the same time, the need for significant funding on the way to a green economy as part of sustainable development remains undeniable.

That is why the concept of green (sustainable, climate) finance appeared, one of the instruments of which is green bonds. Supranational financial institutions were the first issuers of green bonds. Thus, the European Investment Bank was the first issuer of climate awareness bonds amounted to $600 \mathrm{mln}$ euros in 2007. In 2008, the World Bank (the WB) issued green bonds in 3.35 bln Swedish Krones (The World Bank, PPIAF, 2015). Currently, the list of issuers of green bonds has expanded significantly: corporates, municipalities, and governments. However, the supranational financial institutions as issuers of green bonds remain on this market, although their share has declined. Thus, in 2014, the share in the total volume of green bonds issued by supranational financial institutions was $25.5 \%$, but decreased to 3.6\% in 2020 (Climate Bonds Initiative). To reveal the role of supranational financial institutions in this market, it is necessary to retrospectively consider the features of green bond issues by the two main institutions: the WB and the European Bank for Reconstruction and Development (the EBRD), as well as to show which areas of sustainable development were financed and which countries were the ultimate beneficiaries of green projects. This is particularly important since most of the countries that make a negative contribution to the sustainable environment are primarily developing countries with significant shortages of funding capabilities.

\section{LITERATURE REVIEW}

The study of green finance and, in particular, such a tool as green debt instruments, is only at the beginning of the journey. After all, these phenomena themselves have arisen recently. For example, green bonds have a history of just over a decade to date. On the one hand, this opens up great opportunities for researchers. On the other hand, it is challenging to study the possible consequences of issuing such specific bonds due to the limited data. At the moment, studies in this area are mainly aimed at exploring the taxonomy of this phenomenon, delineating its place in green finance and the capital market in general.

However, it is necessary to start with the fact that green finance is used to support sustainable development. The concept of sustainable development was created from the SDG definition (Table 1).

Table 1. Preconditions of the SDGs

Source: Eurostat (2020), The World Commission (n.d.), UNDR (2017).

\begin{tabular}{|c|c|}
\hline Stage & Characteristic \\
\hline 1987 & $\begin{array}{l}\text { The World Commission on Environment and Development (WCED) presented in the Brundtland report the definition of } \\
\text { sustainable development, as "Development which meets the needs of the current generations without compromising the } \\
\text { ability of future generations to meet their own needs" }\end{array}$ \\
\hline 1992 & The Rio Declaration on Environment and Development on the Rio Earth Summit \\
\hline 1994 & The Programme of Action of the International Conference on Population and Development (ICPD) \\
\hline 1995 & The World Summit for Social Development and the Beijing Platform for Action \\
\hline 2000 & The Millennium Development Goals derived from the Millennium Declaration \\
\hline 2002 & The World Summit on Sustainable Development \\
\hline 2005 & The 2005 World Summit \\
\hline 2012 & The United Nations (UN) Conference on Sustainable Development (Rio+20) \\
\hline 2015 & $\begin{array}{l}\text { The United Nations General Assembly (UNGA) adopted the "Transforming our world: the } 2030 \text { Agenda for Sustainable } \\
\text { Development" global document. The } 2030 \text { Agenda includes a list of } 17 \text { SDGs and } 169 \text { related targets, which can be reviewed at } \\
\text { the global level within the UN High-Level Political Forum (HLPF) as the central platform of the UN's. The UN releases a Report } \\
\text { on 'Progress towards the Sustainable Development Goals' annually. }\end{array}$ \\
\hline 2015 & $\begin{array}{l}\text { The Third International Conference on Financing for Development took place in Addis Ababa, Ethiopia. Countries were } \\
\text { encouraged to combine public and private resources }\end{array}$ \\
\hline 2017 & $\begin{array}{l}\text { The UNGA adopted a global SDG indicator framework, that consists of } 232 \text { different indicators, but global SDG monitoring } \\
\text { includes data only for about half of them }\end{array}$ \\
\hline 2020 & $\begin{array}{l}\text { The Statistical Commission conducted a comprehensive review of the indicator framework. The revised global indicator list } \\
\text { includes } 231 \text { different indicators. Another such review is planned for } 2025\end{array}$ \\
\hline
\end{tabular}


Source: Compiled based on Eurostat (2020), UNDR (2017).

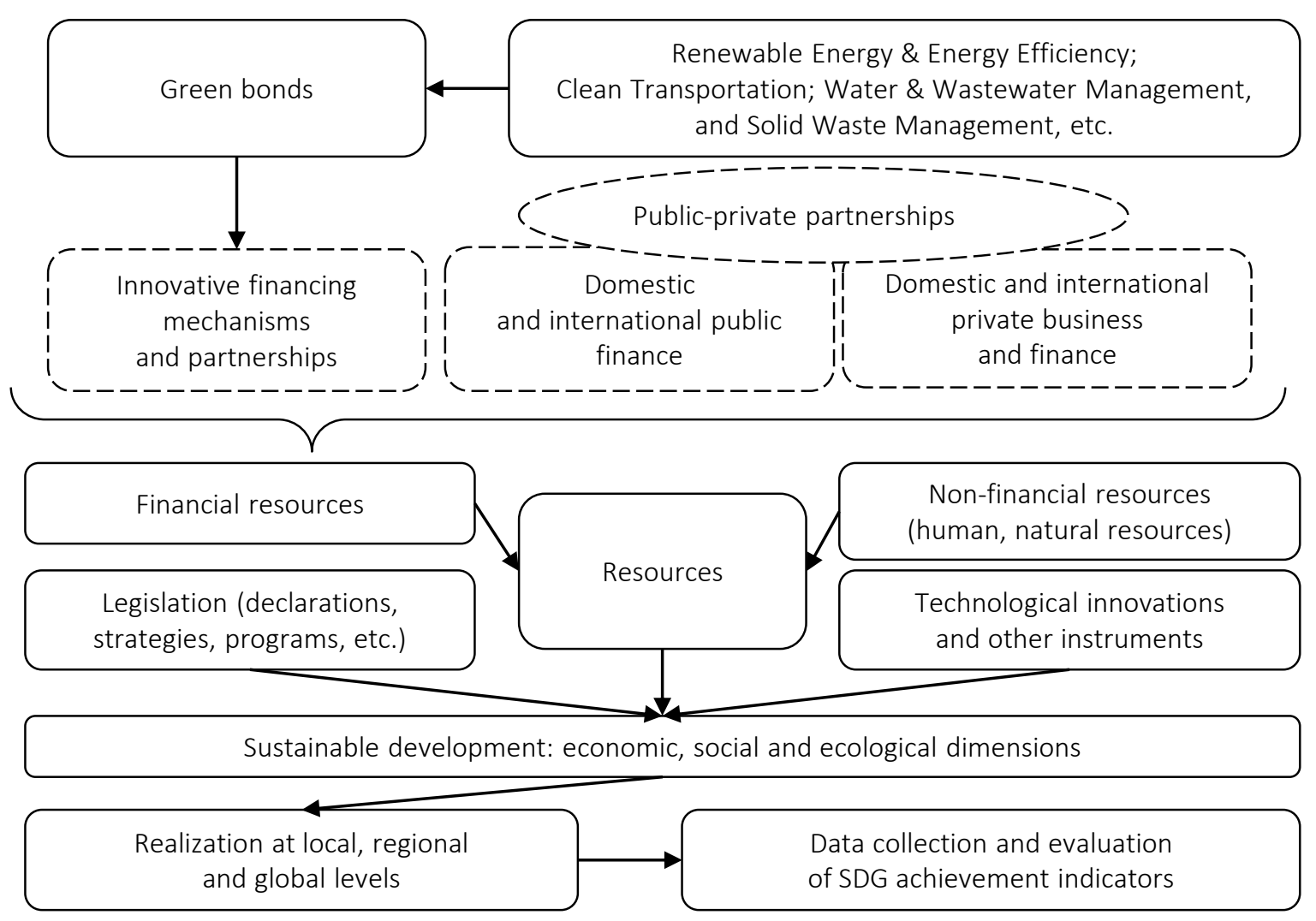

Figure 1. Resources for the implementation of the sustainable development concept

As part of the actions shown in Table 1, local and regional communities approved their own documents. For instance, in 2019, the European Commission presented the European Green Deal aimed at making Europe the first climate-neutral continent by 2050 (European Commission, 2019).

To implement the sustainable development concept, not only the legislation framework is important, but also non-financial and financial resources, technological innovations and other tools (Figure 1).

In addition to Figure 1, it is necessary to mention that green bonds aimed at the realization of ecological dimension of sustainable development with appropriate economic effect and at achieving the social dimension of sustainable development with appropriate economic effect social bonds must be applied.

Experts from supranational financial institutions were among the first researchers of green bonds. Reichelt (2010) shows the importance of issuing green bonds in light of global warming trends and highlights the primary vectors for further research: the definition of green bonds and the motives for investing in such specific instruments. Both of these research vectors are very important. So, if at first green bonds were considered as bonds issued to finance green projects that help to prevent or adapt to climate change (Reichelt, 2010), now the principles of green bonds have been adopted, where green projects are very structured, under which green bonds can be issued (ICMA, 2021). Many works point to the fact that such structuring should not be voluntary but obligatory, and then the green bond market will receive an impetus for further development. For example, Deschryver and de Mariz (2020) note that the lack of international standards inhibits the growth of this market. This is also indicated by Weber and Saravade (2019) when assessing the future of green bonds. In the context of the prospects for the development of the green bond market, the study by Keliuotytè-Staniulènienè \& Daunaravičiūtè (2021) should be noted, which showed that in the context of the COVID-19 pandemic, this market sank. In 
addition, competitive bonds appeared such as social bonds and sustainability bonds. Furthermore, Bhattacharyya (2022) shows that today there are not only green bonds but also climate bonds, sustainability bonds, blue bonds, transition bonds, etc. On the one hand, this diversity provides many opportunities for issuers, but for investors, if certain specific environmental, social, and governance criteria (ESG) guide them, it can create difficulties.

In general, considering the motives for investing in green bonds, then among them, it is undoubtedly necessary to highlight the need for investors' implementation of environmental, social, and governance criteria. The motives for investing in green bonds are also explored by Brammer et al. (2012), Baker et al. (2018), Maltais and Nykvist (2020), and others.

Nevertheless, by far, the main question that requires research is whether the issuance of green bonds actually leads to the achievement of the SDGs, one of which concerns climate action. Six more are related, among other things, to climate change: the conservation of marine ecosystems (life below water) and terrestrial ecosystems (life on land), clean water and sanitation, affordable and clean energy, responsible consumption and production, decent work, and economic growth. Fatica and Panzica (2020) indicate that the issuers of green bonds, in comparison with the issuers of classical bonds, demonstrate a movement towards a decrease in the carbon intensity, which was especially pronounced after the implementation of the Paris Agreement, the aim of which is "... to limit global warming to well below 2 , preferably to 1.5 degrees Celsius, compared to pre-industrial levels" (The Paris Agreement, 2015).

However, there are studies, in particular, Tuhkanen and Vulturius (2020), which, on the contrary, provide facts about greenwashing and, in fact, the issuers of green bonds did not achieve the goals for which they were issued. Also, these authors point to the need to develop policies that would discourage the non-fulfillment of obligations by green bond issuers. In this context, it is also necessary to pay attention to the study by Gilchrist et al. (2021) who draw attention to the fact that the criteria for evaluating issuers of green bonds are vague, and therefore this reduces the interest of such issuers to follow specific rules of corporate greenness, and does not allow policymakers to assess the effectiveness of achieving the SDGs correctly.

Developing countries might choose to ignore many of the blind spots mentioned above. First of all, developing countries are short on funds to do actions toward the low-carbon economy. In this case, the Paris Agreement article "Making finance flows consistent with a pathway towards low greenhouse gas emissions and climate-resilient development" is essential (The Paris Agreement, 2015). Also, developing countries have problems at the legislative and executive levels in the field of green projects and, accordingly, green finance. That is why the participation of supranational financial institutions in green financing is essential for such countries when financial and technical support is crucial. Therefore, the aim of this paper is to identify the features of green bond issues and implemented green projects by the WB and the EBRD, in particular, with an emphasis on issuing green bonds for Ukraine.

\section{DATA AND METHODOLOGY}

The analysis covers financial (funding volumes using green bonds structured thematically and geographically between 2008-2021) and non-financial $\left(\mathrm{CO}_{2}\right.$ emissions per capita and $\mathrm{CO}_{2}$ emissions per 2015 US\$ of GDP between 1992-2018) data. The countries and regions were chosen to show the geography of $\mathrm{CO}_{2}$ emissions and green bond issues, and green projects implemented by the WB (active in almost 170 economies across such regions - Africa, East Asia and Pacific, Europe and Central Asia, Latin America and Caribbean, Middle East and North Africa, South Asia) and the EBRD (active in almost 40 economies across such regions - the Southern and Eastern Mediterranean, to Central and Eastern Europe, to Central Asia). The data have been obtained from the WB (based on calendar/fiscal year) and the EBRD (based on a calendar year) databases. This study is based on the use of different statistical methods for data processing. Structural analysis was used to describe the green projects type and geography. Trend analysis was applied to show trends issues volumes of green, social and sustainability bonds on national and supranational levels. Descriptive 
statistics on $\mathrm{CO}_{2}$ emissions are given to understand the situation in the context of the regions depending on their economic development level. The changes in the structure of green bonds issues in the context of main types of green projects and regions were assessed.

\section{RESULTS}

\subsection{Why green bonds are important in moving towards a zero-carbon economy}

As noted above, sustainable development is closely related to solving environmental issues. An important issue that is acutely faced by the countries is the reduction of $\mathrm{CO}_{2}$ emissions and movement towards creating a low-carbon economy, and at best, a zero-carbon economy. Significant differences between regions, especially given the region's income level, were recognized, looking at $\mathrm{CO}_{2}$ emissions by analyzing metrics such as $\mathrm{CO}_{2}$ emissions per capita and CO2 emissions per 2015 USD of GDP.

These two indicators help shape the vision of the issue. The main trends of these indicators are shown in Figure 2. First of all, in terms of per capita emissions, four regions were leading, North
America, Europe and Central Asia, Middle East and North Africa, East Asia and Pacific. These are regions where the economy is quite well developed, which means there is a need for energy resources, which were recently represented by hydrocarbons. Secondly, the last three regions were characterized by the fact that the values of $\mathrm{CO}_{2}$ emissions per 2015 USD of GDP were higher in countries with lower income levels. That is, high-income countries are implementing many measures to reduce $\mathrm{CO}_{2}$ emissions. Thirdly, in these regions, except for the Middle East and North Africa, there was a steady trend in reducing $\mathrm{CO}_{2}$ emissions per 2015 USD of GDP (in accordance to the WB statistical data base).

In support of these statements, it is necessary to pay attention to Table 2. It is evident that middle and lower middle-income countries have particular issues in moving towards a low-carbon economy. Thus, the average values of $\mathrm{CO}_{2}$ emissions per 2015 USD of GDP for the regions indicated above without considering high-income countries are several times higher than the data with including high-income countries. Also, ranges and interquartile ranges, which characterize the scatter of data, are significantly higher for lower-income countries. Fankhauser and Jotzo (2017) show that "Six of the top 10 emitters are now developing countries, and developing countries as a block

Table 2. Descriptive statistics of $\mathrm{CO}_{2}$ emissions per 2015 USD of GDP between 1992-2018

Source: Compiled based on the World Bank dataset.

\begin{tabular}{|c|c|c|c|c|c|c|c|c|c|c|c|}
\hline Country name & Mean & Median & $\begin{array}{c}\text { First } \\
\text { quartile }\end{array}$ & $\begin{array}{c}\text { Third } \\
\text { quartile }\end{array}$ & $\begin{array}{l}\text { Interquar- } \\
\text { tile range }\end{array}$ & $\begin{array}{l}\text { Standard } \\
\text { deviation }\end{array}$ & Kurtosis & Skewness & Range & Min & Max \\
\hline $\begin{array}{l}\text { East Asia \& Pacific (excl. high } \\
\text { income) }\end{array}$ & 1,092 & 1,085 & 1,018 & 1,188 & 0,171 & 0,185 & $-0,134$ & $-0,041$ & 0,713 & 0,740 & 1,453 \\
\hline East Asia \& Pacific & 0,676 & 0,675 & 0,643 & 0,714 & 0,070 & 0,043 & $-0,730$ & $-0,386$ & 0,156 & 0,586 & 0,742 \\
\hline China & 1,235 & 1,207 & 1,095 & 1,340 & 0,245 & 0,291 & 0,100 & 0,567 & 1,122 & 0,764 & 1,886 \\
\hline $\begin{array}{l}\text { Europe \& Central Asia (excl. } \\
\text { high income) }\end{array}$ & 1,377 & 1,263 & 1,074 & 1,721 & 0,647 & 0,396 & $-1,284$ & 0,363 & 1,210 & 0,871 & 2,082 \\
\hline Europe \& Central Asia & 0,386 & 0,377 & 0,336 & 0,427 & 0,091 & 0,076 & $-0,275$ & 0,621 & 0,277 & 0,280 & 0,558 \\
\hline Ukraine & 3,460 & 3,027 & 2,566 & 4,525 & 1,959 & 1,157 & $-1,495$ & 0,256 & 3,548 & 1,833 & 5,382 \\
\hline South Asia & 0,948 & 0,950 & 0,918 & 0,990 & 0,072 & 0,054 & $-0,556$ & $-0,447$ & 0,182 & 0,840 & 1,022 \\
\hline India & 1,113 & 1,097 & 1,061 & 1,180 & 0,119 & 0,094 & $-0,652$ & $-0,068$ & 0,331 & 0,940 & 1,271 \\
\hline $\begin{array}{l}\text { Latin America \& Caribbean } \\
\text { (excl. high income) }\end{array}$ & 0,326 & 0,325 & 0,316 & 0,339 & 0,023 & 0,014 & $-0,222$ & $-0,337$ & 0,056 & 0,292 & 0,349 \\
\hline Latin America \& Caribbean & 0,345 & 0,345 & 0,337 & 0,359 & 0,022 & 0,016 & 0,637 & $-0,694$ & 0,065 & 0,304 & 0,369 \\
\hline North America & 0,375 & 0,374 & 0,309 & 0,439 & 0,130 & 0,074 & $-1,357$ & $-0,019$ & 0,225 & 0,261 & 0,486 \\
\hline Middle East \& North Africa & 0,781 & 0,782 & 0,766 & 0,798 & 0,033 & 0,025 & $-0,422$ & $-0,222$ & 0,094 & 0,729 & 0,824 \\
\hline $\begin{array}{l}\text { Middle East \& North Africa } \\
\text { (excl. high income) }\end{array}$ & 0,996 & 0,993 & 0,967 & 1,014 & 0,047 & 0,035 & $-0,333$ & 0,532 & 0,130 & 0,940 & 1,069 \\
\hline Africa Eastern and Southern & 0,769 & 0,782 & 0,701 & 0,837 & 0,136 & 0,076 & $-0,991$ & $-0,561$ & 0,251 & 0,619 & 0,870 \\
\hline Africa Western and Central & 0,338 & 0,336 & 0,278 & 0,388 & 0,110 & 0,064 & $-1,519$ & 0,159 & 0,181 & 0,255 & 0,436 \\
\hline Sub-Saharan Africa & 0,582 & 0,613 & 0,511 & 0,648 & 0,137 & 0,075 & $-1,491$ & $-0,329$ & 0,209 & 0,466 & 0,675 \\
\hline
\end{tabular}


$\mathrm{CO}_{2}$ emissions (metric tons per capita)
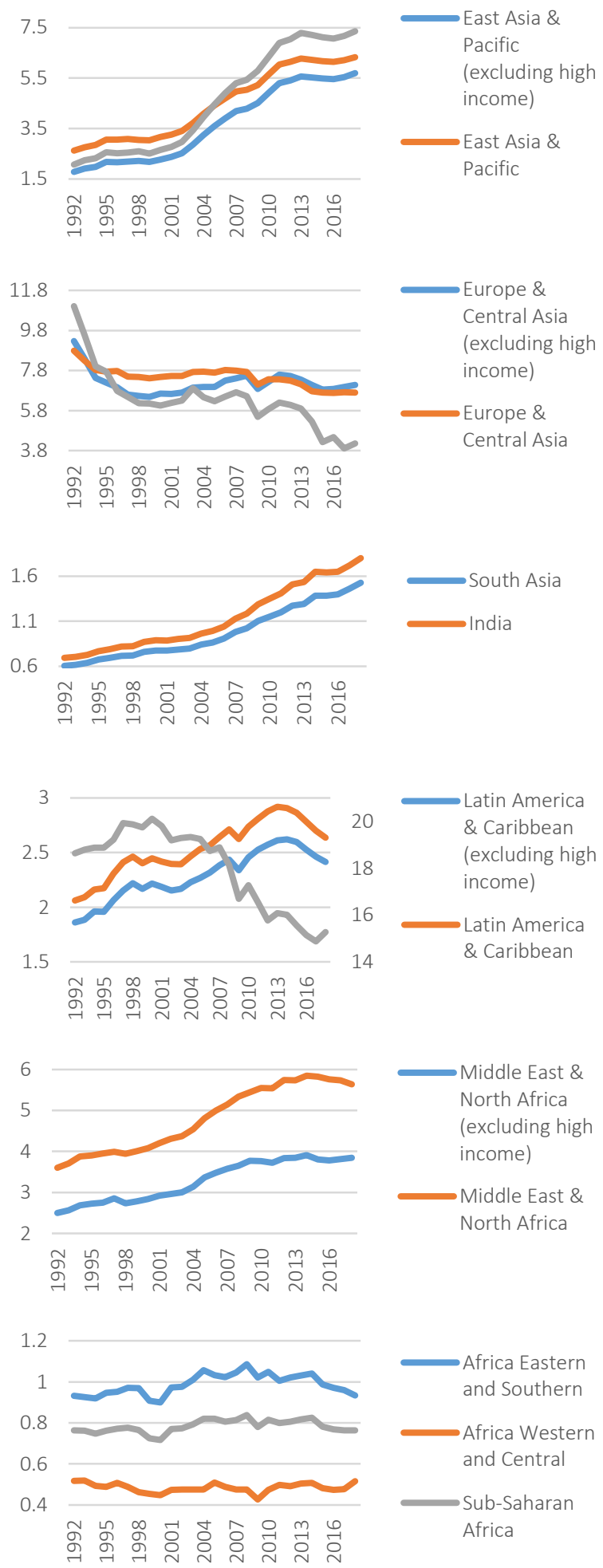

$\mathrm{CO}_{2}$ emissions ( $\mathrm{kg}$ per 2015 USD of GDP)
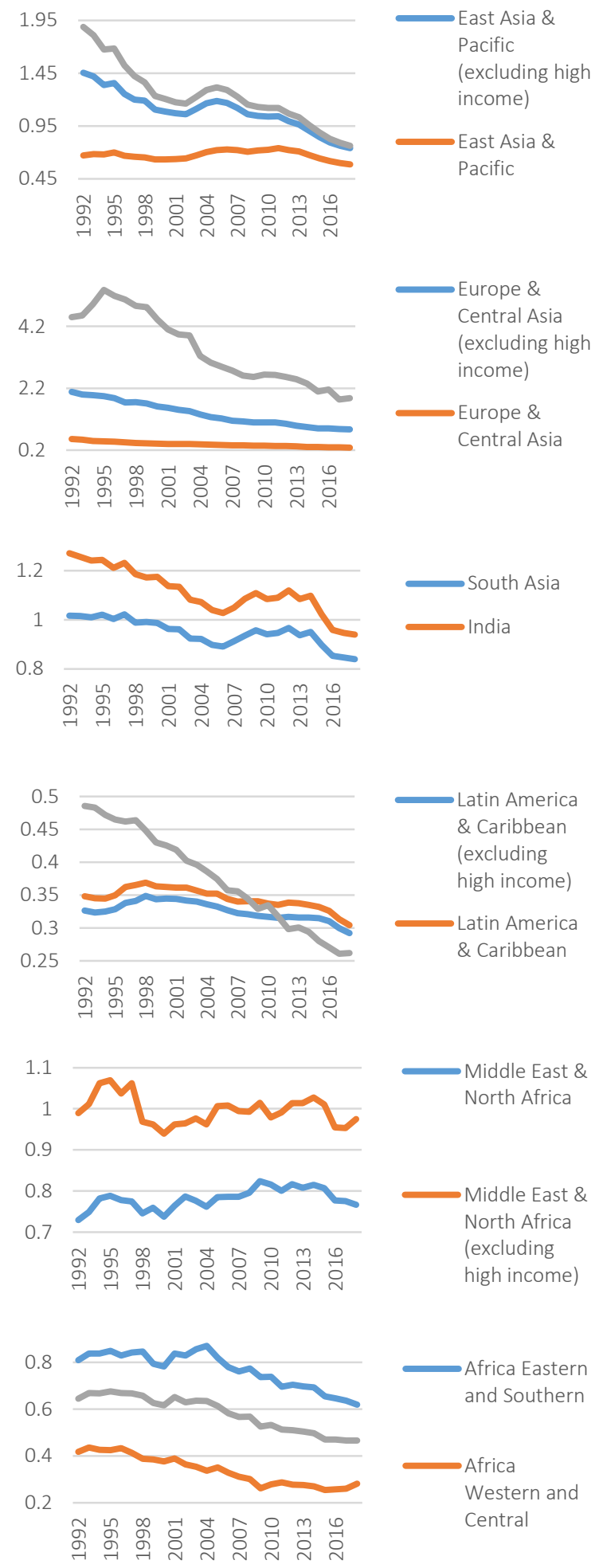

Figure 2. $\mathrm{CO}_{2}$ emissions per capita and $\mathrm{CO}_{2}$ emissions per 2015 USD of GDP between 1992-2018 


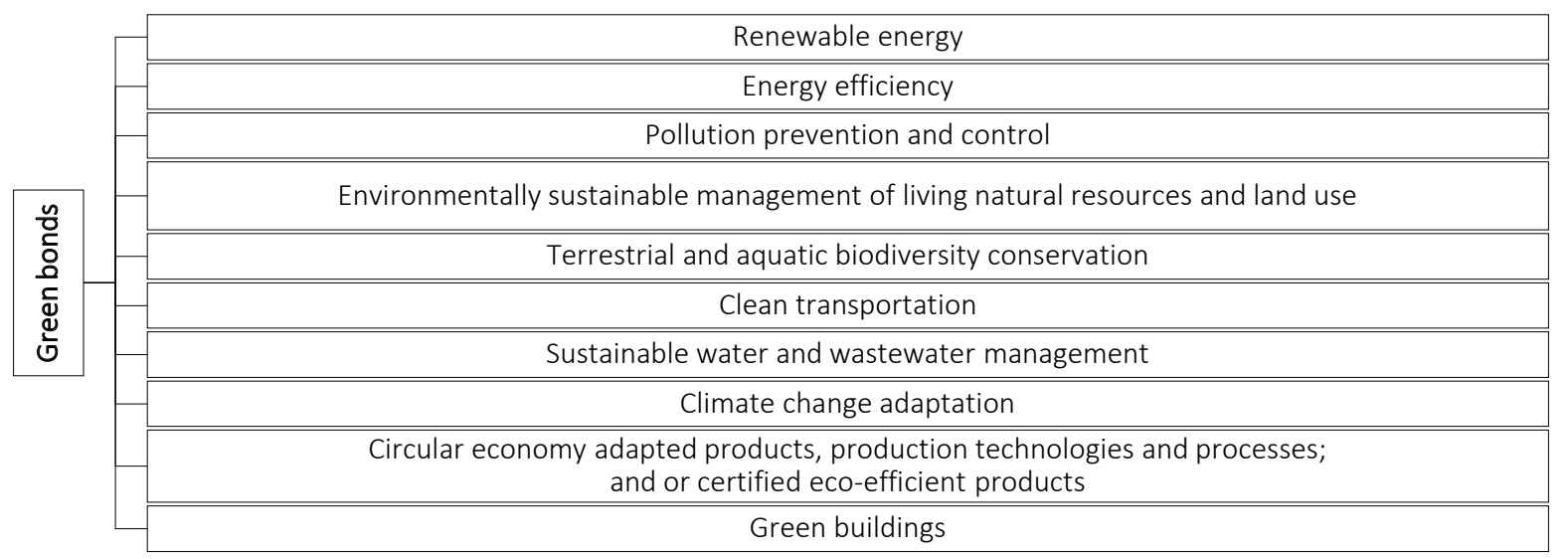

Figure 3. Green bonds according to green projects

account for around 60 percent of total annual emissions. They will be responsible for practically all emissions growth from now on". For example, Ukraine, which is located in Eastern Europe, is a lower-income country characterized by a relatively high dependence on hydrocarbons and, accordingly, has high $\mathrm{CO}_{2}$ emissions per 2015 USD of GDP, although this country also shows a downward trend in emissions.

At the same time, it should be reconsidered that the development of the economy requires the use of a large number of resources, among which energy resources are currently decisive. The use of hydrocarbon resources leads to global warming and environmental pollution, so it is necessary to switch over and look for alternative energy sources. Oddly enough, but COVID-19 visualized this problem in the literal sense. Just the title of the article written by Picheta (2020), "People in India can see the Himalayas for the first time in 'decades,' as the lockdown eases air pollution," said a lot. It means that funding is required, which is a feasible task for high-income countries and an issue for lower-income countries. That is why the green bond initiative that initially came from supranational financial institutions is so important. It should be noted that not only energy but also water and land resources are also depleted, and it is necessary to implement projects in this direction, both for land irrigation, water purification, soil restoration, and many others. However, funding alternative energy is the most important because global warming, if not stopped, will have tragic consequences.
Funding for green projects can be carried out differently and at different levels. However, securities will be most appropriate in case of raising a significant amount of funds. Debt securities, in particular bonds, occupy a special place among securities. There are many types of bonds, depending on the issuers, income opportunities, and purpose. Figure 3 shows the main types of projects for which green bonds can be issued. In turn, investors understand that both economic and environmental effects will be obtained. Such a clearly proclaimed purpose of the use of funds, in addition to ESG motives, also provides the psychological effect of making a contribution to sustainable development.

As mentioned above, today, due to the shift in priorities due to COVID-19, the range of targeted bonds has expanded and competitive bonds have appeared such as social bonds and sustainability bonds (Figure 4).

Figure 5 provides the trends in the issuance of these bonds by the supranational financial institutions, developed and developing countries. Social and sustainability bonds gained particular prominence during the COVID-19 pandemic. Also, supranational financial institutions remain essential players in these special bonds' markets, particularly leaders in sustainability bond issues. The issue volumes of these bonds are significantly lower in emerging markets, which underlines the importance of financial intermediation of supranational financial institutions for those countries. 


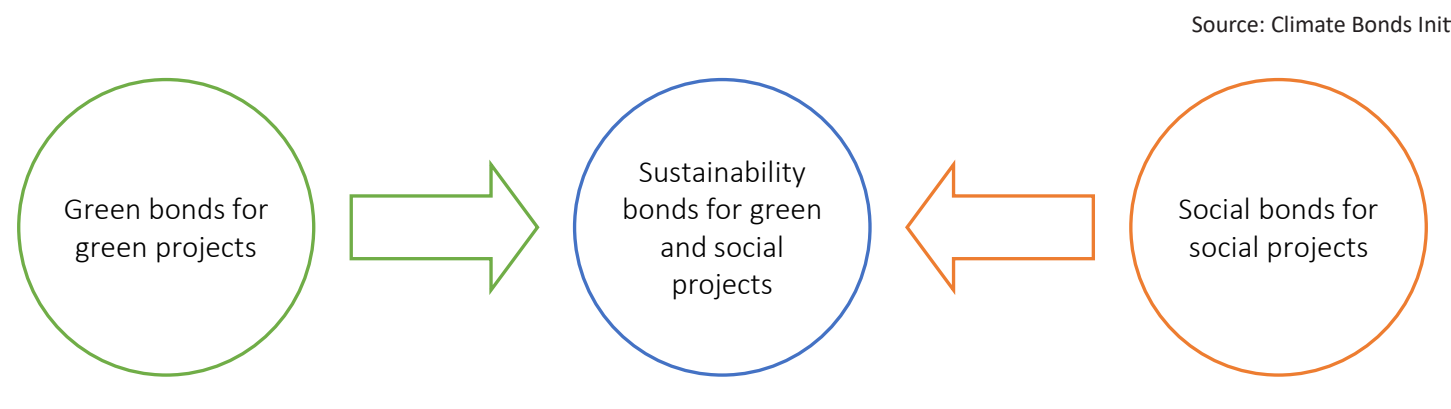

Figure 4. Green, social, and sustainability bonds

Source: Climate Bonds Initiative.

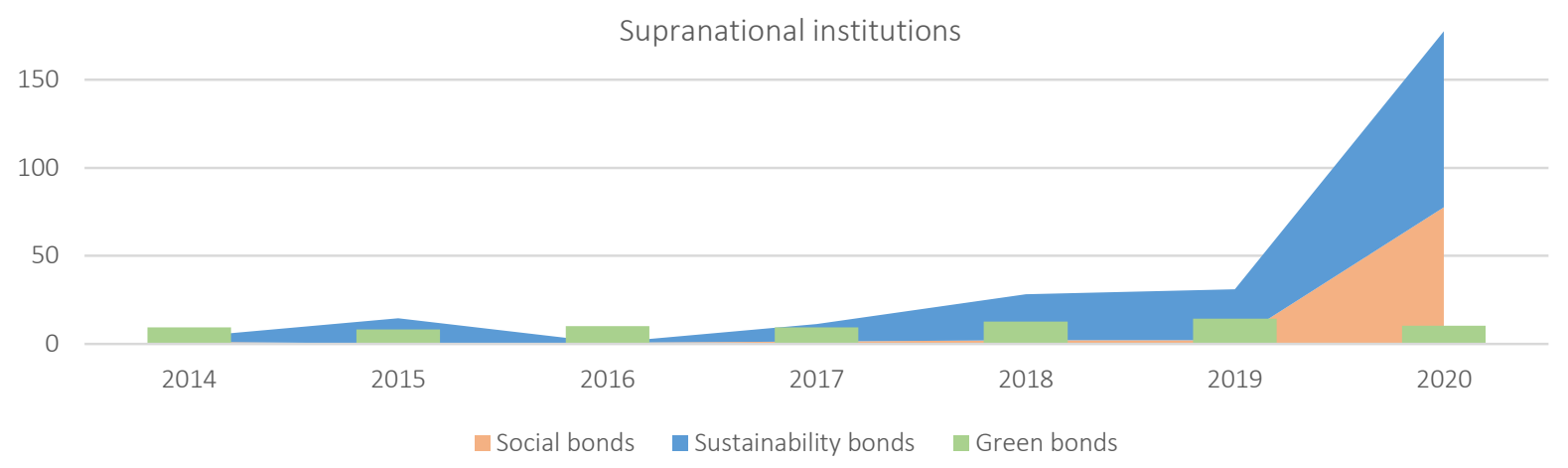

Developed countries

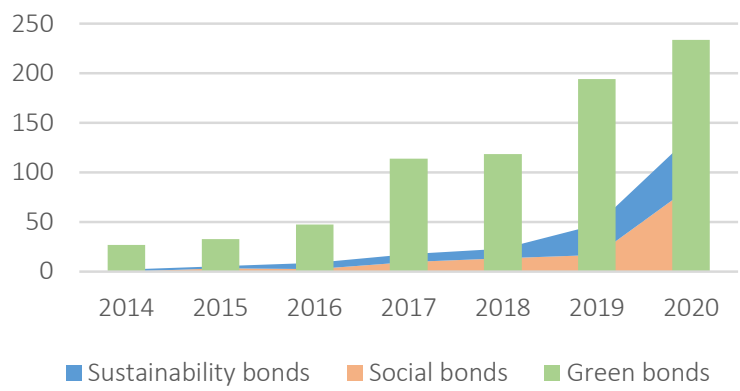

Emerging countries

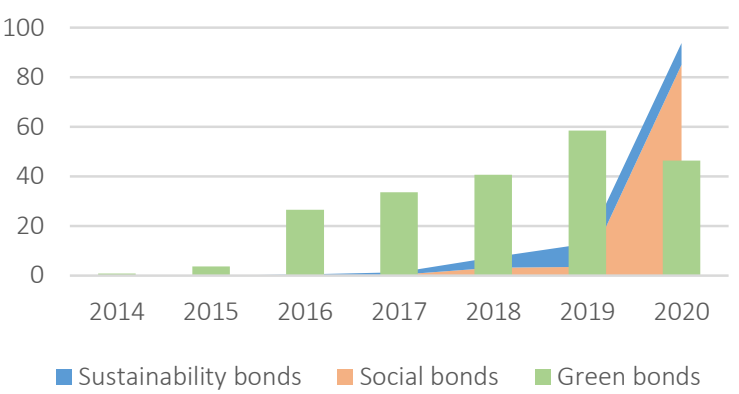

Figure 5. Green, social and sustainability bonds, issued amount, USD bln

\subsection{The WB's green bonds and projects}

The WB assessment of green bond issues can be carried out in two lines: the green bond issues peculiarities and projects financed with borrowed funds.

The first line implies the frequency analysis of 303 green bond issues from November 2008 to December 2021 with the following remarks. Green bonds were issued for more than USD 16,4 billion during this period. The largest green bond issues were carried out in 2014, 2018, and 2021 (Figure 6). On the whole, a positive trend is observed in ma- turity and volumes, which undoubtedly makes it possible to implement more capital-intensive and longer-term projects. At the same time, $95 \%$ of the issued bonds have a maturity of up to 10 years. Currencies must be taken into account when considering interest rates. For example, estimating the interest rate on issues in US dollars, in most cases it was up to $1 \%$.

The currency structure of issued green bonds was wide, but USD, EUR, SEK, and AUD prevailed (Figure 7).

Regarding the second line, the study period includes 2015-2020. It is also worth noting the data 
Source: The World Bank dataset.

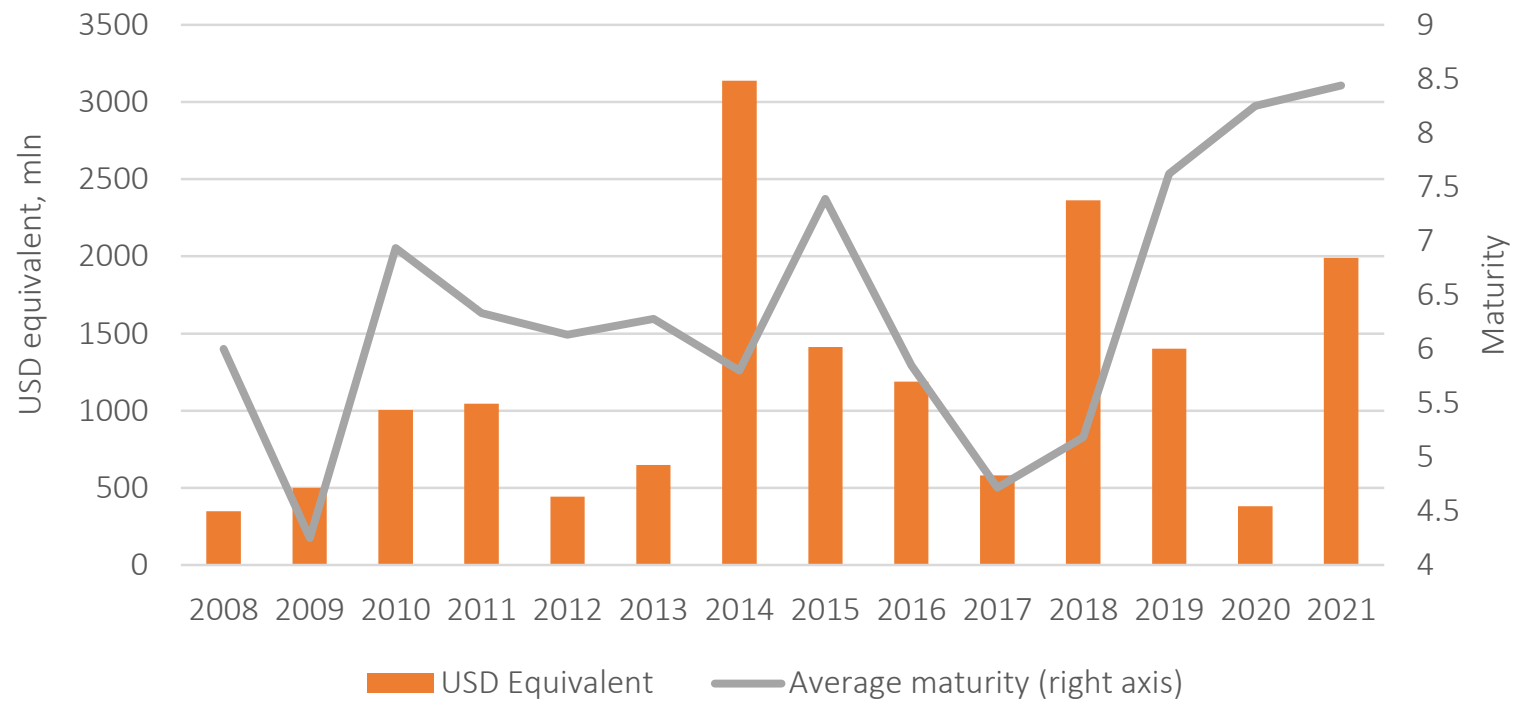

Figure 6. Green bond issues by the WB and average maturity of issues, 2008 - November 30, 2021

Source: The World Bank dataset.

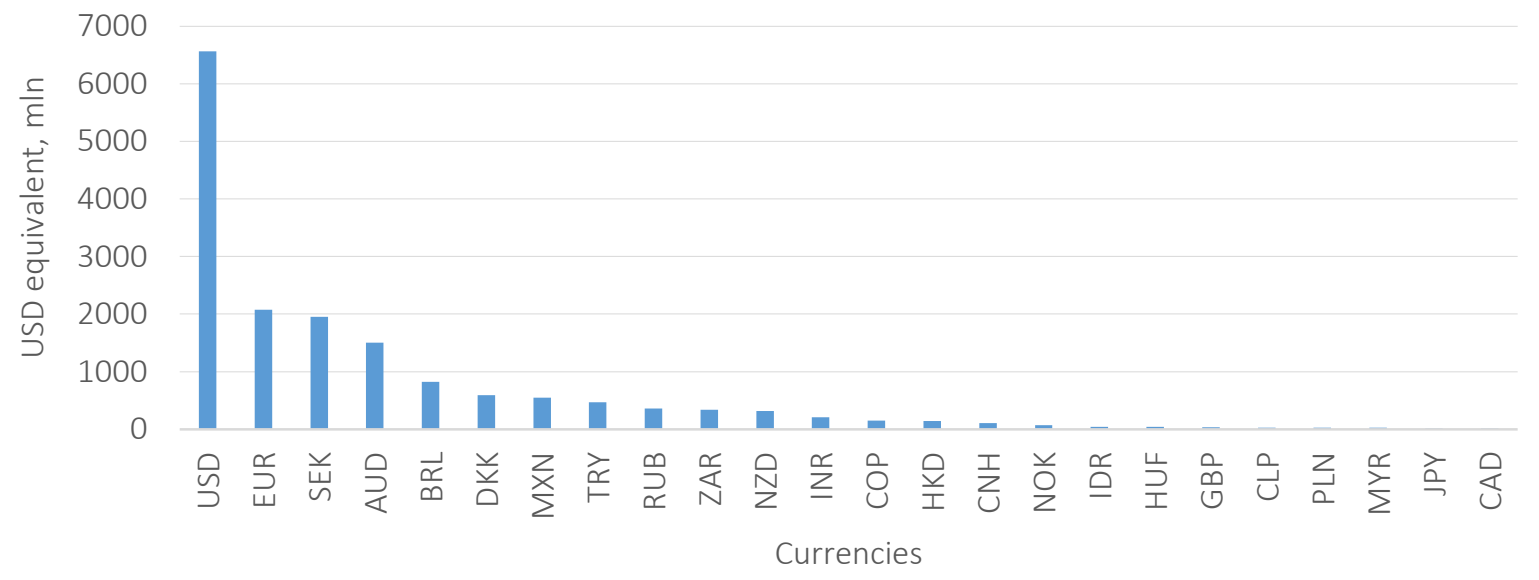

Figure 7. Currency structure of green bonds issued by the WB, 2008 - November 30, 2021

features: they are the fiscal year data and cumula- Thus, the main resources were directed to finance tive data. Tables 3 and 4 provide analysis results. projects in three countries: China, India, and Renewable Energy \& Energy Efficiency and Clean Turkey. Assessing the situation with $\mathrm{CO}_{2}$ in these Transportation projects are the World Bank's pri- countries, it is evident that it deviates significantly ority using green bonds. So, as of 2020, these pro- from the average for the region (China) or forms jects took 63\%. These two areas are primarily re- it (India). Projects implemented in these countries sponsible for the $\mathrm{CO}_{2}$ situation and constructing a focused on the construction of hydroelectric or low-carbon economy.

The analysis of the countries receiving funds from the World Bank shows apparent leaders. These countries - China and India - have significant issues with $\mathrm{CO}_{2}$ pollution and the environment. They account for $45.86 \%$ of all funds spent on June 30, 2020 (Table 4). geothermal power plants, changes in agricultural practices to reduce greenhouse gas emissions, and support for energy efficiency projects.

The implemented projects in Ukraine were also projects in Renewable Energy \& Energy Efficiency. Ultimately, the funding from the World Bank amounted to 360 million US dollars. These two 
Table 3. Type structure of green projects financed by the WB in 2015-2020 fiscal years, $\%$

Source: Compiled based on the World Bank Green Bond Impact Report 2015-2020.

\begin{tabular}{|c|c|c|c|c|c|}
\hline Type & $\begin{array}{c}\text { Renewable } \\
\text { Energy \& Energy } \\
\text { Efficiency }\end{array}$ & $\begin{array}{c}\text { Clean } \\
\text { Transportation }\end{array}$ & $\begin{array}{l}\text { Water \& Wastewater } \\
\text { Management, and Solid } \\
\text { Waste Management }\end{array}$ & $\begin{array}{l}\text { Agriculture, Land } \\
\text { Use, Forests } \\
\text { \& Ecological } \\
\text { Resources }\end{array}$ & $\begin{array}{c}\text { Resilient } \\
\text { Infrastructure, Built } \\
\text { Environment, and } \\
\text { Other }\end{array}$ \\
\hline Year & 1 & 2 & 3 & 4 & 5 \\
\hline 2015 & 38.35 & 33.62 & 9.33 & 11.52 & 7.18 \\
\hline 2016 & 37.14 & 35.10 & 9.15 & 12.51 & 6.10 \\
\hline 2017 & 40.20 & 32.84 & 9.42 & 11.66 & 5.89 \\
\hline 2018 & 39.52 & 33.60 & 9.40 & 11.61 & 5.87 \\
\hline 2019 & 36.37 & 29.79 & 8.54 & 17.10 & 8.20 \\
\hline 2020 & 36.21 & 26.71 & 11.18 & 18.06 & 7.84 \\
\hline
\end{tabular}

Table 4. Geographic structure of green projects financed by the WB in 2015-2020 fiscal years, \%

Source: Compiled based on the World Bank Green Bond Impact Report 2015-2020.

\begin{tabular}{|c|c|c|c|c|c|c|}
\hline Year & 2015 & 2016 & 2017 & 2018 & 2019 & 2020 \\
\hline Country & 1 & 2 & 3 & 4 & 5 & 6 \\
\hline China & 28.65 & 29.44 & 30.22 & 31.22 & 29.31 & 23.29 \\
\hline India & 17.97 & 17.11 & 17.97 & 17.90 & 20.22 & 21.96 \\
\hline Turkey & 9.99 & 9.49 & 8.73 & 8.22 & 7.90 & 9.32 \\
\hline Morocco & 3.33 & 5.07 & 4.73 & 4.93 & 4.29 & 5.91 \\
\hline Colombia & 4.30 & 4.10 & 3.21 & 3.20 & 4.07 & 5.81 \\
\hline Brazil & 7.74 & 7.70 & 6.90 & 6.87 & 5.44 & 5.45 \\
\hline Mexico & 10.75 & 9.48 & 9.49 & 9.46 & 7.19 & 4.59 \\
\hline Belarus & 0.66 & 0.63 & 0.58 & 0.58 & 0.60 & 3.62 \\
\hline Philippines & 4.52 & 4.30 & 4.01 & 4.00 & 3.83 & 3.32 \\
\hline Ecuador & 0.73 & 2.12 & 1.98 & 1.97 & 3.12 & 3.13 \\
\hline Indonesia & 2.41 & 2.29 & 2.14 & 2.13 & 2.93 & 2.93 \\
\hline Ukraine & 3.89 & 3.24 & 2.74 & 2.73 & 2.10 & 2.10 \\
\hline Other & 5.06 & 5.03 & 7.31 & 6.79 & 9.00 & 8.57 \\
\hline
\end{tabular}

projects aim to create energy independence in Ukraine, which is currently the most serious problem.

\subsection{The EBRD's green bonds and projects}

If the WB green bonds disclose the global level of SDG financing, then the EBRD green bonds disclose the regional level of SDG financing. The general characteristic of the EBRD Green Project Portfolio (GPP) is shown in Table 5.

As Table 5 shows, the total number of green projects from 2016 to 2020 was not less than 350 with total operating assets not less than $€ 3.5$ billion and weighted average tenor not less than 11 years. This period is explained by the needed longevity

Table 5. General characteristic of GPP of the EBRD, 2016-2020

Source: Compiled based on the EBRD Sustainability Report 2015-2020, www.ebrd.com.

\begin{tabular}{|c|c|c|c|c|c|}
\hline Year & 2016 & 2017 & 2018 & 2019 & 2020 \\
\hline Indicators & 1 & 2 & 3 & 4 & 5 \\
\hline Total operating assets, $€$ billion & 6.1 & 3.9 & 8.0 & 4.49 & 3.75 \\
\hline Total undisbursed commitments, € billion & 3.9 & 3.7 & 3.75 & 3.77 & 3.66 \\
\hline Number of projects & 352 & 390 & 378 & 380 & 355 \\
\hline Weighted average remaining life, years & 9.1 & 10.2 & 10.22 & 10.19 & 10.22 \\
\hline Weighted average tenor, years & 11.9 & 12.7 & 12.93 & 13.06 & 13.68 \\
\hline Total committed amounts approved, $€$ billion & $n / a$ & 2.8 & 1.433 & 1.7 & 0.819 \\
\hline Total of new operating assets approved, $€$ million & $n / a$ & 397 & 468 & 416 & 237 \\
\hline Total of undisbursed commitments approved, € billion & $n / a$ & 2.4 & 0.695 & 1.29 & 0.582 \\
\hline
\end{tabular}


Table 6. Type structure of green projects financed by the EBRD in 2015-2020, \%

Source: Compiled based on the EBRD Sustainability Report 2015-2020, www.ebrd.com.

\begin{tabular}{|c|c|c|c|c|c|}
\hline Type & $\begin{array}{c}\text { Energy } \\
\text { efficiency }\end{array}$ & $\begin{array}{c}\text { Clean / renewable } \\
\text { energy }\end{array}$ & $\begin{array}{l}\text { Environmental services and } \\
\text { sustainable public transport }\end{array}$ & $\begin{array}{c}\text { Water } \\
\text { management }\end{array}$ & $\begin{array}{c}\text { Waste } \\
\text { management }\end{array}$ \\
\hline Year & 1 & 2 & 3 & 4 & 5 \\
\hline 2015 & 49.6 & 23.8 & 15.1 & 11.3 & 0.3 \\
\hline 2016 & 53.7 & 21.6 & 13.2 & 11.0 & 0.5 \\
\hline 2017 & 48 & 25 & 15 & 11 & 1 \\
\hline 2018 & 49.1 & 28.2 & 13.6 & 8.3 & 0.8 \\
\hline 2019 & 40.5 & 37.0 & 14.9 & 6.7 & 0.9 \\
\hline 2020 & 29.3 & 43.4 & 19.4 & 6.8 & 1.1 \\
\hline
\end{tabular}

of the implementation of green projects, the type structure of which is shown in Table 6.

Table 6 shows that priority types of green projects are the following: clean/renewable energy (from $23.8 \%$ in 2015 to $45.4 \%$ in 2020 ); energy efficiency (from $49.6 \%$ in 2015 to $29.3 \%$ in 2020 ); environmental services and sustainable public transport (from $11.3 \%$ in 2015 to $19.4 \%$ in 2020). From these data it follows that in 2019-2020 the priority of green projects types was slightly redistributed mostly towards clean/renewable energy. This means that energy efficiency projects did not bring a significant decrease in $\mathrm{CO}_{2}$. The more $\mathrm{CO}_{2}$ emissions a country has, the more green projects the country tries to implement (Table 7).
As shown in Table 7, the most significant green project financing by the EBRD belongs to not only European countries such as Poland (from 15\% in 2015 to $9.4 \%$ in 2020), Romania (from 13\% in 2015 to $3.4 \%$ in 2020), and Serbia (from 5\% in 2015 to $4.7 \%$ in 2020), but also to non-European countries such as Turkey (from 32\% in 2015 to $26 \%$ in 2020), Russia (from 5\% in 2015 to $2.9 \%$ in 2019), Ukraine (from $3 \%$ in 2016 to $6.2 \%$ in 2020), Jordan (from $2 \%$ in 2016 to $5.8 \%$ in 2020), Morocco (from $2 \%$ in 2016 to $4.3 \%$ in 2020), and Egypt (from $1.1 \%$ in 2017 to $11.5 \%$ in 2020 ).

One of the most important indicators of green projects financed by the EBRD is the real impact of their implementation (Table 8).

Table 7. Geographic structure of green projects financed by the EBRD in 2015-2020, \% Report 2015-2020, www.ebrd.com.

\begin{tabular}{|c|c|c|c|c|c|c|}
\hline Year & 2015 & 2016 & 2017 & 2018 & 2019 & 2020 \\
\hline Country & 1 & 2 & 3 & 4 & 5 & 6 \\
\hline Turkey & 32 & 38 & 35.2 & 32.5 & 27.4 & 26.0 \\
\hline Poland & 15 & 18 & 15.8 & 13.5 & 12.6 & 9.4 \\
\hline Romania & 13 & 9 & 8.7 & 7.7 & 3.6 & 3.4 \\
\hline Serbia & 5 & 3 & 3.1 & 4.4 & 3.8 & 4.7 \\
\hline Russia & 5 & 4 & 3.7 & 3.1 & 2.9 & $\mathrm{n} / \mathrm{a}$ \\
\hline Slovak Republic & 3 & 2 & 1.9 & $\mathrm{n} / \mathrm{a}$ & $\mathrm{n} / \mathrm{a}$ & $\mathrm{n} / \mathrm{a}$ \\
\hline Croatia & 3 & 2 & 1.7 & $\mathrm{n} / \mathrm{a}$ & $\mathrm{n} / \mathrm{a}$ & $\mathrm{n} / \mathrm{a}$ \\
\hline Kazakhstan & 3 & 3 & 3.8 & 3.5 & 2.2 & $\mathrm{n} / \mathrm{a}$ \\
\hline Bulgaria & 2 & 2 & 1.7 & $\mathrm{n} / \mathrm{a}$ & $\mathrm{n} / \mathrm{a}$ & $\mathrm{n} / \mathrm{a}$ \\
\hline Ukraine & $\mathrm{n} / \mathrm{a}$ & 3 & 2 & 2.9 & 7.8 & 6.2 \\
\hline Georgia & $\mathrm{n} / \mathrm{a}$ & 2 & 1.7 & $\mathrm{n} / \mathrm{a}$ & $\mathrm{n} / \mathrm{a}$ & $\mathrm{n} / \mathrm{a}$ \\
\hline Jordan & $\mathrm{n} / \mathrm{a}$ & 2 & 3.2 & 4.9 & 5.8 & 5.8 \\
\hline Morocco & $\mathrm{n} / \mathrm{a}$ & 2 & 3.1 & 3.3 & 3.9 & 4.3 \\
\hline Egypt & $\mathrm{n} / \mathrm{a}$ & $\mathrm{n} / \mathrm{a}$ & 1.1 & 4.2 & 9.5 & 11.5 \\
\hline Other & 19 & 10 & 13.1 & 20 & 20.6 & 28.7 \\
\hline
\end{tabular}


Table 8. Total impact of green projects financed by the EBRD in 2015-2020, \%

Source: Compiled based on the EBRD Sustainability Report 2015-2020, www.ebrd.com.

\begin{tabular}{|c|c|c|c|c|c|c|c|}
\hline \multirow{2}{*}{ Project type } & \multirow{2}{*}{ Indicators } & 2015 & 2016 & 2017 & 2018 & 2019 & 2020 \\
\hline & & 1 & 2 & 3 & 4 & 5 & 6 \\
\hline \multirow[t]{2}{*}{ Climate Projects } & $\begin{array}{l}\text { Greenhouse Gas reduced (million tons } \mathrm{CO} 2 \text { equivalent } \\
\text { annually) }\end{array}$ & $\mathrm{n} / \mathrm{a}$ & 7.4 & 12.2 & 12.7 & 14 & 27 \\
\hline & Capacity Installed (Gigawatt) & $\mathrm{n} / \mathrm{a}$ & $\mathrm{n} / \mathrm{a}$ & 2.7 & 3.5 & 4.1 & 6.9 \\
\hline \multirow{4}{*}{$\begin{array}{l}\text { Water Projects and } \\
\text { Waste Management } \\
\text { Projects }\end{array}$} & Benefitting people, million & $\mathrm{n} / \mathrm{a}$ & 9.1 & 17.4 & 21.85 & 23 & $\mathrm{n} / \mathrm{a}$ \\
\hline & Water savings (million $\mathrm{m}^{3}$ annually) & 11.7 & 28.8 & 123 & 206 & 210 & 394 \\
\hline & Wastewater treated (million $\mathrm{m}^{3}$ annually) & $\mathrm{n} / \mathrm{a}$ & $\mathrm{n} / \mathrm{a}$ & 137 & 128 & 184 & $n / a$ \\
\hline & $\begin{array}{l}\text { Reduce waste disposal and improve recycling (million } \\
\text { tonnes annually) }\end{array}$ & 0.24 & 0.87 & $\mathrm{n} / \mathrm{a}$ & 3.4 & 4 & $\mathrm{n} / \mathrm{a}$ \\
\hline \multirow{2}{*}{$\begin{array}{l}\text { Sustainable } \\
\text { Transportation Projects }\end{array}$} & Reduction in Particulate Matter (tonnes annually) & $\mathrm{n} / \mathrm{a}$ & $\mathrm{n} / \mathrm{a}$ & $\mathrm{n} / \mathrm{a}$ & 19 & 17 & $\mathrm{n} / \mathrm{a}$ \\
\hline & Reduction in Nitrogen Oxides (tonnes annually) & $\mathrm{n} / \mathrm{a}$ & $\mathrm{n} / \mathrm{a}$ & $\mathrm{n} / \mathrm{a}$ & 455 & 239 & $\mathrm{n} / \mathrm{a}$ \\
\hline
\end{tabular}

Table 9. Examples of green projects financed by the EBRD in 2015-2020, \%

Source: Compiled based on the EBRD Sustainability Report 2015-2020, www.ebrd.com.

\begin{tabular}{|c|c|c|c|}
\hline Project & $\begin{array}{c}\text { EBRD } \\
\text { investment }\end{array}$ & Sector & Benefits \\
\hline $\begin{array}{l}\text { A new trolleybus fleet for the city } \\
\text { of Kremenchuk }\end{array}$ & $€ 8$ million & Transport & Pollution reduction \\
\hline $\begin{array}{l}\text { Rehabilitation of Hrybovychi } \\
\text { landfill and the building of } \\
\text { a mechanical and biological } \\
\text { treatment facility, Lviv }\end{array}$ & $€ 20$ million & $\begin{array}{l}\text { Manufacturing and } \\
\text { services }\end{array}$ & $\begin{array}{l}\text { This investment will improve the efficiency of the solid } \\
\text { waste management system, including the separation and } \\
\text { collection of recycling material. It will also contribute to } \\
\text { the city's targeted } 20 \text { per cent reduction in } \mathrm{CO}_{2} \text { emissions } \\
\text { by } 2020\end{array}$ \\
\hline Nova Poshta SDG9 & $€ 9.5$ million & Transport & $\begin{array}{l}\text { The proceeds will be used to automate the existing } \\
\text { infrastructure to optimize the supply chain. The project } \\
\text { will allow } \mathrm{CO}_{2} \text { emission reductions of } 1,600 \text { tonnes per } \\
\text { year }\end{array}$ \\
\hline $\begin{array}{l}\text { Low carbon pathways: } \\
\text { trolleybuses in Kharkiv and Kryvyi } \\
\text { Rih SDG9 }\end{array}$ & $€ 16$ million & Transport & $\begin{array}{l}\text { The proceeds were used for fleet renewal and } \\
\text { infrastructure modernization }\end{array}$ \\
\hline Kamianka Solar & $€ 18.5$ million & Power and Energy & N/a \\
\hline Ukrposhta logistics development & $€ 63$ million & Transport & $\begin{array}{l}\text { Support the reorganization of Ukrposhta's branch } \\
\text { network }\end{array}$ \\
\hline Fozzy Group & $\begin{array}{l}\text { US\$ } 60 \text { million } \\
\text { long-term EBRD } \\
\text { loan }\end{array}$ & $\begin{array}{l}\text { Manufacturing and } \\
\text { services }\end{array}$ & Building the first green supermarket in Ukraine \\
\hline
\end{tabular}

Table 8 shows that climate projects reduce greenhouse gas emissions, namely 27 million tons $\mathrm{CO}_{2}$ equivalent annually; water projects and waste management projects save 394 million $\mathrm{m}^{3}$ of water annually and treated 184 million $\mathrm{m}^{3}$ of wastewater annually; sustainable transportation projects reduce 239 Nitrogen Oxides tonnes annually.

It is also necessary to pay attention to some examples of green projects in Ukraine financed by the EBRD (Table 9).

To summarize all of the above, it is necessary to emphasize the importance of EBRD green bonds in the implementation of the sustainable develop- ment concept not only in European countries, but especially in non-European countries.

\section{DISCUSSION}

The study showed that the green bond market had changed significantly since their first issues in terms of the structure of leading issuers: the share of supranational financial institutions has decreased many times. However, the role of these institutions as green bond issuers is vital in green project funding in developing countries. In fact, the issuers on the green bond market are predominantly developed countries. So, their share among issuers of green bonds averaged $71 \%$ for 2014-2020, while the share of developing countries was only $18 \%$. 
Supranational financial institutions actually act as intermediaries between developing countries and investors. There are several reasons for this. First, a high level of confidence and creditworthiness of supranational financial institutions makes it possible to attract funds at relatively low-interest rates and for a long time. Second, the ability to attract funds both in hard and local currencies (the latter is critical if there is a danger of currency devaluation). Third, the ability to prioritize (renewable energy and energy efficiency, clean transportation, water and wastewater management, agriculture and land use, forests and ecological resources, resilient infrastructure, and others). Fourth, control over the spending of funds and encouragement of local companies and governments to participate in projects, ensuring their further support. Therefore, it is crucial that international financial institutions continue to be essential players in this market and be pioneers in innovation, particularly in forming strategic directions for green and social projects. In this regard, further study may be focused on new financial instruments issued by the WB and EBRD, such as sustainability and social bonds.

\section{CONCLUSION}

This paper identified the features of green bond issues and implemented green projects by the WB and the EBRD, with an emphasis on issuing green bonds for Ukraine.

Given the need to finance sustainable development, it was shown that the issuance of green bonds by supranational financial institutions gave impetus to the development of this market and the emergence of new bonds markets that combined the goals of both green and social bonds - sustainability bonds. Despite the fact that at the moment corporations and states are the leaders in issuing green bonds, the role of supranational financial institutions remains essential, since emerging countries still need the support of a financial intermediary as their ratings do not allow attracting funds at an affordable price and in the required amount to finance green projects.

Some important findings from the analysis of green bond issues by the World Bank and EBRD could be highlighted. Firstly, the share of green bonds issued by supranational financial institutions has decreased due to significant structural changes in its development: governments and corporations have also become green bond issuers. Secondly, the volume of green bonds issuance and green project funding by the WB and the EBRD have recovered quickly, despite the decline in 2020 due to the pandemic and the shift of the focus rather on social challenges. Thirdly, at the moment, the primary directions of green projects financed by green bonds are renewable energy, energy efficiency, and clean transportation, which is relatively consistent with the intentions of many economies to become low-carbon or zero-carbon economies: the WB - as of the fiscal year 2019-2020, these projects took 63\%; the EBRD - as of 2020 these projects took $82.1 \%$. Fourthly, the main countries receiving the most funds from the WB are China and India, which accounted for $45.9 \%$ of total project funding in the 2019-2020 fiscal year. These countries receive substantial funding for green projects as they remain among the leaders in $\mathrm{CO}_{2}$ emissions in their regions, but at the same time, they demonstrate their intention to reduce it to an acceptable level. The main countries that received funds for the implementation of green projects from the European Bank for Reconstruction and Development in 2020 were Turkey (26\%), Poland (9.4\%), and Egypt (11.5\%), which accounted for 46.9\% in total funds.

As for Ukraine, the WB financed Renewable Energy \& Energy Efficiency projects, and the EBRD financed Power and Energy, Transport, Manufacturing and services projects. These projects are important because Ukraine's transition to energy independence and security, as well as the modernization of a clean transport infrastructure, is the most urgent need today.

Thus, efforts to build sustainable funding for emerging economies in achieving the SDGs will be on the agenda of the WB and the EBRD, and, most likely, their activities in this direction will be trend-determining in the future. 


\section{AUTHOR CONTRIBUTIONS}

Conceptualization: Nataliia Versal.

Data curation: Nataliia Versal, Antonina Sholoiko.

Formal analysis: Nataliia Versal, Antonina Sholoiko.

Investigation: Nataliia Versal, Antonina Sholoiko.

Methodology: Nataliia Versal, Antonina Sholoiko.

Project administration: Antonina Sholoiko.

Supervision: Nataliia Versal.

Visualization: Nataliia Versal, Antonina Sholoiko.

Writing - Nataliia Versal, Antonina Sholoiko.

Writing - review \& editing: Nataliia Versal, Antonina Sholoiko.

\section{ACKNOWLEDGMENTS}

The authors would like to thank the participants of the 1st International Conference on Sustainable Development (SDL 2021) for providing the valuable remarks and a fruitful discussion. This research received no specific grant from any funding agency in the public, commercial, or not-for-profit sectors.

\section{REFERENCES}

1. Amundi Asset Management Company, International Finance Corporation (IFC). (2021). Emerging Market Green Bonds Report 2020: On the Road to Green Recovery. Retrieved from https://www.ifc.org/wps/ wcm/connect/0fab2dcd-25c948cd-b9a8-d6cc4901066e/IFC + Amundi+Emerging+Marke $\mathrm{t}+$ Green+Bonds+Report +202 0+\%2816April21\%29.pdf?M$\mathrm{OD}=\mathrm{AJPERES} \& \mathrm{CVID}=\mathrm{nzGuFTM}$

2. Baker, M., Bergstresser, D., Serafeim, G., \& Wurgler, J. (2018). Financing the Response to Climate Change: The Pricing and Ownership of US Green Bonds (National Bureau of Economic Research Working paper 25194). https://doi. org/10.3386/w25194

3. Bhattacharyya, R. (2022). Green finance for energy transition, climate action, and sustainable development: overview of concepts, applications, implementation and challenges. Green Finance, 4(1), 1-35. https://doi.org/10.3934/ GF.2022001

4. Brammer, S., Jackson, G., \& Matten, D. (2012). Corporate Social Responsibility and Institutional Theory: New Perspectives on Private Governance. Socio-Economic
Review, 10(1), 3-28. https://doi/ org/10.1093/ser/mwr030

5. Climate Bonds Initiative. (n.d.). Retrieved from https://www.climatebonds.net/market/data/

6. Deschryver, P., \& de Mariz, F.R. (2020). What future for the green bond market? How can policymakers, companies, and investors unlock the potential of the green bond market? Journal of Risk and Financial Management, 13(3), 1-26. https://doi.org/10.3390/ jrfm13030061

7. Dou, X. (2015). The essence, feature and role of low carbon economy. Environment, Development and Sustainability, 17, 123-136. https://doi.org/10.1007/ s10668-014-9542-9

8. European Bank. (n.d.). Sustainability Reports (2014, 2015, 2016, 2017, 2018, 2019, 2020). Retrieved from https://www.ebrd.com/news/ publications.html

9. European Commission. (2019). The European Green Deal, COM (2019) 640 final. Brussels.

10. Eurostat. (2020). Sustainable development in the European Union: Monitoring report on progress towards the SDGs in an
EU context (2020). Retrieved from https://ec.europa.eu/eurostat/web/ products-statistical-books/-/ks02-20-202

11. Fankhauser, S., \& Jotzo, F. (2017). Economic growth and development with low-carbon energy (Working paper, 301). Retrieved from https://assets. publishing.service.gov.uk/media/5a2532fded915d458b922ee6/ Working-paper-267-FankhauserJotzo.pdf

12. Fatica, S., \& Panzica, R. (2020). Green bonds as a tool against climate change? (Working Papers 2020-10). Joint Research Centre, European Commission (Ispra site).

13. Gilchrist, D., Yu, J., \& Zhong, R. (2021). The Limits of Green Finance: A Survey of Literature in the Context of Green Bonds and Green Loans. Sustainability, 13, 478. https:// doi.org/10.3390/ su13020478.

14. ICMA. (2021). Green Bond Principles: Voluntary Process Guidelines for Issuing Green Bonds, June 2021. Retrieved from https:// www.icmagroup.org/assets/documents/Sustainable-finance/2021updates/Green-Bond-PrinciplesJune-2021-140621.pdf 
15. Ignatyuk, A., Liubkina, O., Murovana, T., \& Magomedova, A. (2020). FinTech as an innovation challenge: from big data to sustainable development. E3S Web Conf. 16613027. https://doi.org/10.1051/e3sconf/202016613027

16. Keliuotytè-Staniulènienè, G., \& Daunaravičiūtè, K. (2021). The Global Green Bond Market in the Face of the COVID-19 Pandemic. Financial Markets, Institutions and Risks, 5(1), 50-60.

17. Leitao, J., Ferreira, J., \& Santibanez-Gonzalez, E. (2021). Green bonds, sustainable development and environmental policy in the European Union carbon market. Business Strategy and the Environment, 30(4), 2077-2090.

18. Maltais, A., \& Nykvist, B. (2020). Understanding the role of green bonds in advancing sustainability. Journal of Sustainable Finance \& Investment. https://doi.org/10.1080 /20430795.2020.1724864

19. Picheta, R. (2020). People in India can see the Himalayas for the first time in 'decades,' as the lockdown eases air pollution. CNN. Retrieved from https://edition.cnn.com/ travel/article/himalayas-visiblelockdown-india-scli-intl/index. html

20. Reichelt, H. (2010). Green bonds: a model to mobilize private capital to fund climate change mitigation and adaptation projects. Retrieved from https:// www.semanticscholar.org/paper/ Green-bonds-\%3A-a-model-tomobilize-private-capital-Reichelt/ d1d0a0c5ed56d70072d052fb9a3df93d4985e746

21. Ricke, K., \& Caldeira, K. (2014). Maximum warming occurs about one decade after a carbon dioxide emission. Environmental Research Letters, 9(12). Retrieved from https://iopscience.iop.org/article /10.1088/1748-9326/9/12/124002/ pdf

22. Roser, M. (2021). Why did renewables become so cheap so fast? Retrieved from https://ourworldindata.org/cheap-renewablesgrowth
23. The Paris Agreement. (n.d.). Retrieved from https://unfccc.int/ process-and-meetings/the-parisagreement/the-paris-agreement

24. The World Bank. (n.d.). Green Bond Impact Reports (2015, 2016, 2017, 2018, 2019, 2020). Retrieved from https://treasury.worldbank. org/en/about/unit/treasury/ibrd/ ibrd-green-bonds

25. The World Bank. (n.d.a). Green Bonds since 2008. Retrieved from https://finances.worldbank.org/ Other/Green-Bonds-since-2008/ ayy5-fxut

26. The World Bank. (n.d.b). World Bank Open Data. Retrieved from https://data.worldbank.org/

27. The World Bank, PPIAF. (2015). What are green bonds? Washington, D.C.: World Bank Group. Retrieved from http://documents.worldbank.org/curated/ en/400251468187810398/Whatare-green-bonds

28. The World Commission. (n.d.). Report of the World Commission on Environment and Development: Our Common Future. Retrieved from http://www.un-documents. net/wced-ocf.htm

29. Tuhkanen, H. \& Vulturius, G. (2020). Are green bonds funding the transition? Investigating the link between companies' climate targets and green debt financing. Journal of Sustainable Finance \& Investment. https://doi.org/10.1080 /20430795.2020.1857634

30. UNDR. (2017). Global Trends: Challenges and Opportunities in the Implementation of the SDGs. Retrieved from https://www.undp. org/publications/global-trendschallenges-and-opportunitiesimplementation-sdgs

31. United Nations. (n.d.). THE 17 GOALS | sustainable development. Retrieved from https://sdgs. un.org/ru/goals

32. Versal, N. I., \& Sholoiko, A. S. (2021). Can green bonds help in 'Seeing the Himalayas'? SDL 2021: Book of Abstracts of the 1st Virtual International Conference on Sustainable Development (April 23-25, 2021) / Ed. by Volodymyr Goshylyk. Ivano-Frankivsk.
33. Weber, O., \& Saravade, V. (2019). Green bonds - current development and their future. Center for International Governance Information Paper, 210. Retrieved from https://www.cigionline.org/publications/green-bonds-currentdevelopment-and-their-future/ 